Gitation: Valencia-Romero, R., Martínez-García, M. A., SánchezBárcenas, H., \& Ríos-Bolívar, H. (2021). Mexican demand for rice imports (Oryza sativa L.) during NAFTA: evidence from a NARDL model with structural change and outliers. Agro Productividad. https://doi. org/10.32854/agrop.v14i8.1947

Editor in Chief: Dr. Jorge Cadena Iñiguez

Received: February, 2021 Accepted: August, 2021

Estimated publication date: September, 2021

This work is licensed under a Creative Commons Attribution-NonCommercial 4.0 International license.

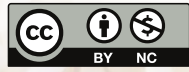

\section{Mexican demand for rice imports (Oryza sativa L.) during NAFTA: evidence from a NARDL model with structural change and outliers}

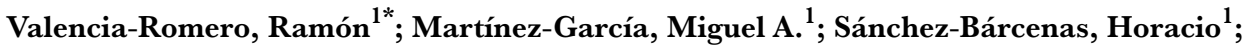 \\ Ríos-Bolívar, Humberto ${ }^{1}$ \\ 1 Escuela Superior de Economía, Instituto Politécnico Nacional, Unidad Profesional Lázaro Cárdenas. \\ Alcaldía Miguel Hidalgo, CDMX, México, C.P.11350. \\ * Corresponding author: rvalenciaro@ipn.mx
}

\begin{abstract}
Objective: This study aimed to determine which model best captures the behaviour of rice imports during the North America Free Trade Agreement (NAFTA) regime (1994-2018).

Methodology: Mexican demand for rice imports is estimated with Autoregressive Distributed Lag Model (ARDL) and Nonlinear Autoregressive Distributed Lag Model (NARDL), both with and without structural change and outliers.

Results: It starts with the ARDL and NARDL models, obtaining non-cointegration, as well as diagnosis and specification problems. Subsequently an ARDL model is proposed with structural change and outliers, which represents an improvement but still has specification problems. Finally, the best model is obtained incorporating non-linearity.

Limitations/Implications: It is a study for a specific grain, so the results obtained are only valid for rice imports. Nevertheless, it must be considered that it is a basic grain. Moreover, a new methodology is used to estimate the import demand function.

Findings: There is evidence of an asymmetric response of rice imports to fluctuations in economic activity and the exchange rate in the short run, and only in the long run for the latter. An increase in rice imports with NAFTA is also confirmed, as well as two extraordinary variations of rice imports during the study period.
\end{abstract}

Keywords: Rice imports; ARDL; NARDL; structural change; outliers.

\section{INTRODUCTION}

Despite divergences, neoclassical economic theory as well as post-Keynesianism have converged on the view that import demand is a function of income (economic activity) and the relative price of imports, in national currency. The first theory operates through the imperfect substitution of goods, using utility maximization (Goldstein \& Khan, 1985; Leamer \& Stern, 1970), and the second one analyses economic growth through demand (Thirlwall, 2002). Empirical studies for Mexico have maintained this theoretical structure of demand, using Gross Domestic Product (GDP) - recently the Global Indicator of 
Economic Activity (GIEA) ${ }^{[1]}$ - and the real exchange rate index as proxy variables of income and the relative price of imports, obtaining income and price elasticities of import demand when the calculation is done with logarithms. The import demand function has been calculated for various periods and with various econometric methodologies for the Mexican economy (Cardero \& Galindo, 1999; Cermeño \& Rivera Ponce, 2016; Loria Díaz, 2001; Moreno-Brid, 2002; Pacheco-López, 2005; Romero, 2010; Valencia, 2008). A brief description of the research prior to 2000 can be found in Moreno-Brid (2002).

All these previous studies suggest that import demand has been extensively studied in the case of Mexico. These studies have been concentrated at the aggregate level of imports, considering trade liberalization in 1994, when the North America Free Trade Agreement (NAFTA) came into force ${ }^{[2]}$. However, there are still points to analyse. First, none of the research mentioned has focused on imports of a basic grain, such as rice. Second, Mexico eliminated import tariffs on rice only in 2003, instead of 1994. Third, national production of rice could be affected by financial crisis or/and weather problems, and as a result imports would change. Fourth, rice imports may respond asymmetrically to fluctuations in the exchange rate and GIEA ${ }^{[3]}$.

Therefore, the central hypothesis is that import demand of rice reacts asymmetrically to variations in the exchange rate and economic activity. Also, NAFTA (in 2003 and 2008, instead of 1994), as well as extraordinary events (financial crises and climate problems), affected the behaviour of these imports. In this sense, this document extends the literature of import demand, adding not only asymmetry but also structural change (NAFTA) and outliers, without changing the fundamental point that a basic grain is analysed.

Globally, rice provides 20 percent of food energy supply; thus it is key to food security (FAO, 2004). It is also one of the three food grains (along with wheat and maize) that predominates in cultivated area and production (FAO, 2019). In Mexico, rice is the second grain -behind only maize- that represents the highest expense for Mexican households on food, beverages, and tobacco (INEGI, 2013). In addition, rice ranks fourth in production of food grains, behind maize, beans, and wheat (Ireta-Paredes et al., 2015). In this sense, rice is strategic, not only nutritionally but also economically. Despite its relevance, the rice supply in Mexico has become exogenous, that is, it is increasingly composed of imports (Figure 1). In this context, it is undoubtedly interesting to study rice imports.

\section{METHODS: ARDL AND NARDL MODELS}

Empirically, import demand has been represented with the following equation:

\footnotetext{
${ }^{1}$ The GIEA uses the same methodology as GDP, but monthly instead of quarterly (INEGI, 2019b).

${ }^{2}$ NAFTA was a trade bloc to eliminate or reduce barriers to trade and investment between Canada, Mexico, and the United States. NAFTA has been replaced by the new United States-Mexico-Canada Agreement (USMC), which was signed on November 30, 2018 (United States-Mexico-Canada Agreement, 2019).

${ }^{3}$ Recently, empirical evidence of asymmetry has been found in different goods; for example, asymmetry response of fuel demand for road transport in Korea (Chi, 2018), of tourism demand in ten European countries (Irandoust, 2019), of energy demand in OECD and non-OECD countries (Liddle \& Sadorsky, 2020), even of the money demand in the United Kingdom (Bahmani-Oskooee \& Nayeri, 2020).
} 


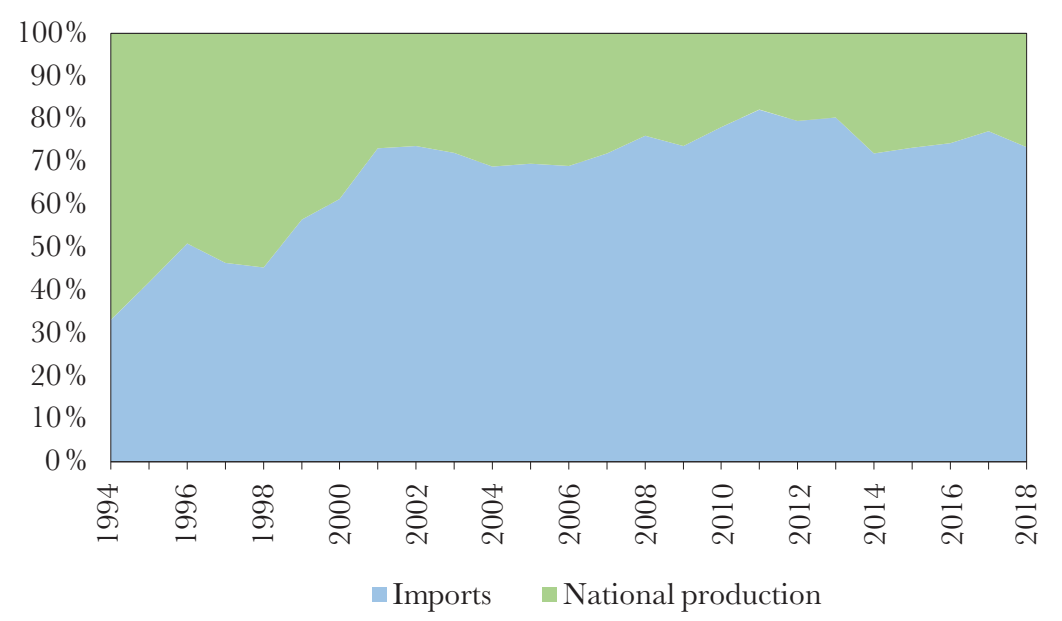

Figura 1. Evolution of rice supply in Mexico.

Source: Own elaboration with information of FAO (2019).

$$
l m_{t}=\beta_{1} l r+\beta_{2} l a+u_{t}
$$

where $l$ indicates the natural logarithm of each variable, $m$ is rice imports, $r$ is the exchange rate, and $a$ is the GIEA. Moreover, $\beta_{1}$ and $\beta_{2}$ are the coefficients of long-run processes; this equation does no show the short run. Pesaran and Shin (1999), through what they called an Autoregressive Distributed Lag Model (ARDL) and its representation in an error correction model, got both effects (short- and long-run) in a single equation:

$$
\Delta l m_{t}=\rho l m_{t-1}+\sum_{j=1}^{n 1} \gamma_{j} \Delta l m_{t-j}+\theta l r_{t-1}+\lambda l a_{t-1}+\sum_{j=0}^{n 2} \pi \Delta l r_{t-j}+\sum_{j=0}^{n 3} \varphi \Delta l a_{t-j}+e_{t}
$$

where $\Delta$ is the difference operator, $\rho$ is the error-correction coefficient, $\gamma_{j}$ are autoregressive coefficients, $\theta$ and $\lambda$ are coefficients of long-run effects, and short-run effects are represented as $\pi$ and $\varphi$. The serially uncorrelated error term is represented by $e_{t}$.

Shin, Yu, and Greenwood-Nimmo (2011) added asymmetry to equation 2. In other words, they considered the possibility that the dependent variable might respond differently to increases rather than to decreases of the independent variables. To add asymmetry, the following series were created:

$$
\begin{aligned}
& l r_{t}^{+}=\sum_{i=1}^{t} \Delta l r_{i}^{+}=\sum_{i=1}^{t} \max \left(\Delta l r_{i}, 0\right) \text { and } l r_{t}^{-}=\sum_{i=1}^{t} \Delta l r_{i}^{-}=\sum_{i=1}^{t} \min \left(\Delta l r_{i}, 0\right) \\
& l a_{t}^{+}=\sum_{i=1}^{t} \Delta l a_{i}^{+}=\sum_{i=1}^{t} \max \left(\Delta l a_{i}, 0\right) \text { and } l a_{t}^{-}=\sum_{i=1}^{t} \Delta l a_{i}^{-}=\sum_{i=1}^{t} \max \left(\Delta l a_{i}, 0\right)
\end{aligned}
$$

These are partial sums of positive and negative changes. Replacing $l r$ and $l a$ in equation 2 with these partial sums produces a Nonlinear Autoregressive Distributed Lag Model (NARDL): 


$$
\begin{aligned}
\Delta l m_{t}= & \rho l m_{t-j}+\sum_{j=1}^{n 1} \gamma_{j} \Delta l m_{t-j}+\theta^{+} l r_{t-1}^{+}+\theta^{-} l r_{t-1}^{-}+\lambda^{+} l a_{t-1}^{+}+\lambda^{-} l a_{t-1}^{-} \\
& +\sum_{j=0}^{n 2}\left(\pi_{j}^{+} \Delta l r_{t-j}^{+}+\pi_{j}^{-} \Delta l r_{t-j}^{-}\right)+\sum_{j=0}^{n 3}\left(\varphi_{j}^{+} \Delta l a_{t-j}^{+}+\varphi_{j}^{-} \Delta l a_{t-j}^{-}\right)+\varepsilon_{t}
\end{aligned}
$$

It is worth mentioning that equation 2 is an ARDL model without structural changes or outliers. But if we wanted to include them, we would have the following equation ${ }^{[4]}$ :

$$
\begin{aligned}
\Delta l m_{t}= & \rho l m_{t-j}+\sum_{j=1}^{n 1} \gamma_{j} \Delta l m_{t-j}+\theta l r_{t-1}+\lambda l a_{t-1}+\sum_{j=0}^{n 2} \pi \Delta l r_{t-j} \\
& +\sum_{j=0}^{n 3} \varphi \Delta l a_{t-j}+\varepsilon_{t}+\sum_{r=1}^{k} \delta_{r} s_{r t}+\sum_{r=1}^{k} \vartheta_{r} o_{r t}+\varepsilon_{t}
\end{aligned}
$$

In the same way, the NARDL model would take the following form:

$$
\begin{aligned}
\Delta l m_{t}= & \rho l m_{t-j}+\sum_{j=1}^{n 1} \gamma_{j} \Delta l m_{t-j}+\theta^{+} l r_{t-1}^{+}+\theta^{-} l r_{t-1}^{-}+\lambda^{+} l a_{t-1}^{+}+\lambda^{-} l a_{t-1}^{-} \\
& +\sum_{j=0}^{n 2}\left(\pi_{j}^{+} \Delta l r_{t-1}^{+}+\pi_{j}^{-} l r_{t-1}^{-}\right)+\sum_{j=0}^{n 3}\left(\varphi_{j}^{+} \Delta l a_{t-1}^{+}+\varphi_{j}^{-} \Delta l a_{t-1}^{-}\right) \\
& +\sum_{r=1}^{k} \delta_{r} s_{r t}+\sum_{r=1}^{k} \vartheta_{r} o_{r t}+\varepsilon_{t}
\end{aligned}
$$

In equations 6 and $7, \sum_{r=1}^{k} \delta_{r} s_{r t}$ and $\sum_{r=1}^{k} \vartheta_{r} o_{r t}$ represent the structural changes and outliers, respectively. In this case $s_{r t}$ is a dummy variable, defined as $s_{r t}=1$ for $\geq T_{s}$, otherwise $s_{r t}=0, \geq T_{s}$, indicates the beginning of structural change; $o_{r t}$ is also a dummy variable, but defined in a different way, $o_{r t}=1$ only for $T_{o}$, the exact time when an outlier happened, and the rest of the time $o_{r t}=0$. Moreover, $\delta_{r}$ and $\vartheta_{r}$ are the coefficients of the respective structural change and outlier.

Finally, cointegration tests, as well as diagnostic and specification tests, are applied to validate the ARDL and NARDL models and evaluate their usefulness.

\section{DATA}

For this study we used national-level data for Mexico during the NAFTA period (19942018). The GIEA(INEGI, 2019b) and the real exchange rate index (BANXICO, 2019) are used to quantify their effects on rice imports (INEGI, 2019a). All variables are seasonally adjusted (base 2013 $=100$ ).

Regarding the structural change in rice imports, NAFTA will be tested. NAFTA began in 1994, but Mexico eliminated import tariffs on rice only in 2003 (Zahniser \& Link, 2002); thus, the structural change of imports will be tested from 2003 instead of 1994. As for outliers in imports, there are two options to test, 2008 and 2016. First, the global financial crisis in 2008 had important economic effects, such as instability in the real exchange rate,

\footnotetext{
${ }^{4}$ Raheem (2018)which is contrary to theoretical argument. The study's estimation is based on both symmetric (linear analysed the dollarization of several countries through ARDL and NARDL models with multiple structural changes, but this research did not consider outliers.
} 
thus generating an outstanding increase and decrease in rice imports throughout 2008. Second, in October 2015 Mexico was afflicted by Hurricane Patricia, the most intense hurricane in the country's history; this affected its western agricultural region, from which Mexico in 2014 had obtained 53.08\% of its national production of rice (SADER, 2020).

\section{RESULTS AND DISGUSSION}

Table 1 presents cointegration, diagnostic, and specification tests for each ARDL and NARDL model; each model with and without structural change (d2003) and outliers (d2008_m9 and d2016_m5). Using the bounds test of Pesaran, Shin, and Smith (2001), this table shows that the variables are not cointegrated in the ARDL and NARDL models (equations 2 and 5, respectively) without structural change and outliers. In addition to non-cointegration, there is non-normality in residuals and incorrect specification. For its part, the ARDL model that incorporates structural change and outliers (equation 6) produces better results: cointegration of variables and residuals are distributed normally. However, Ramsey's RESET test suggests that there are still specification problems, which

Table 1. ARDL and NARDL models (diagnostic, specification, and cointegration bound tests).

\begin{tabular}{|c|c|c|c|c|c|c|c|c|}
\hline \multirow{3}{*}{$\begin{array}{c}\text { STATISTIC } \\
\chi_{H}^{2}\end{array}$} & \multicolumn{4}{|c|}{ No structural change or outliers } & \multicolumn{4}{|c|}{ Structural change and outliers } \\
\hline & \multicolumn{2}{|c|}{$\begin{array}{c}\text { ARDL } \\
\text { equation } 2\end{array}$} & \multicolumn{2}{|c|}{$\begin{array}{c}\text { NARDL } \\
\text { equation } 5\end{array}$} & \multicolumn{2}{|c|}{$\begin{array}{c}\text { ARDL } \\
\text { equation } 6\end{array}$} & \multicolumn{2}{|c|}{$\begin{array}{c}\text { NARDL } \\
\text { equation } 7\end{array}$} \\
\hline & 12.31 & $(0.66)$ & 12.93 & $(0.74)$ & 15.65 & $(0.83)$ & 26.73 & $(0.37)$ \\
\hline$\chi_{S C}^{2}$ & 12.06 & $(0.44)$ & 12.74 & $(0.39)$ & 16.08 & $(0.19)$ & 10.81 & $(0.55)$ \\
\hline$\chi_{N}^{2}$ & 9.06 & $(0.01)$ & 11.42 & $(0.00)$ & 0.59 & $(0.75)$ & 1.16 & $(0.56)$ \\
\hline$F_{F F}$ & 4.61 & $(0.03)$ & 10.34 & $(0.00)$ & 4.45 & $(0.04)$ & 3.47 & $(0.06)$ \\
\hline$F_{C}$ & \multicolumn{2}{|c|}{2.83} & \multicolumn{2}{|c|}{3.39} & \multicolumn{2}{|c|}{7.41} & \multicolumn{2}{|c|}{5.38} \\
\hline$t_{C}$ & \multicolumn{2}{|c|}{-2.83} & \multicolumn{2}{|c|}{-3.13} & \multicolumn{2}{|c|}{-4.19} & \multicolumn{2}{|c|}{-4.47} \\
\hline $\mathrm{R}^{2}$ & \multicolumn{2}{|c|}{0.45} & \multicolumn{2}{|c|}{0.46} & \multicolumn{2}{|c|}{0.54} & \multicolumn{2}{|c|}{0.55} \\
\hline Adjusted R-squared & \multicolumn{2}{|c|}{0.42} & \multicolumn{2}{|c|}{0.44} & \multicolumn{2}{|c|}{0.51} & \multicolumn{2}{|c|}{0.52} \\
\hline Akaike & \multicolumn{2}{|c|}{0.16} & \multicolumn{2}{|c|}{0.13} & \multicolumn{2}{|c|}{0.02} & \multicolumn{2}{|c|}{-0.003} \\
\hline Schwarz & \multicolumn{2}{|c|}{0.34} & \multicolumn{2}{|c|}{0.29} & \multicolumn{2}{|c|}{0.27} & \multicolumn{2}{|c|}{0.26} \\
\hline Hannan-Quinn & \multicolumn{2}{|c|}{0.23} & \multicolumn{2}{|c|}{0.19} & \multicolumn{2}{|c|}{0.12} & \multicolumn{2}{|c|}{0.10} \\
\hline & & & al value & the bou & s test & & & \\
\hline & & ARD & odels & & & NARDI & nodels & \\
\hline & F-bc & test & t-bo & s test & F-boun & st $(k=4)$ & t-bo & s test \\
\hline Significance & $\mathrm{I}(0)$ & $\mathrm{I}(1)$ & $\mathrm{I}(0)$ & $\mathrm{I}(1)$ & $\mathrm{I}(0)$ & $\mathrm{I}(1)$ & $\mathrm{I}(0)$ & $\mathrm{I}(1)$ \\
\hline $10 \%$ & 3.17 & 4.14 & -2.57 & -3.21 & 2.45 & 3.52 & -2.57 & -3.66 \\
\hline $5 \%$ & 3.79 & 4.85 & -2.86 & -3.53 & 2.86 & 4.01 & -2.86 & -3.99 \\
\hline $1 \%$ & 5.15 & 6.36 & -3.43 & -4.1 & 3.74 & 5.06 & -3.43 & -4.6 \\
\hline
\end{tabular}

Notes: $\chi_{H}^{2}, \chi_{S C}^{2}, \chi_{N}^{2}$, and $F_{F F}$ indicate the heteroskedasticity test (White no cross terms), the LM test for serial correlation (Breusch-Godfray), the normality test (Jarque-Bera), and the functional form test (Ramsey's RESET test), respectively. The numbers in parentheses are the associated p-values. Moreover, $F_{C}$ and $t_{C}$ denote the $F$-statistic and $t$-statistic for testing the null hypothesis of no cointegration. 
can be attributed to the presence of nonlinear or asymmetrical effects that this ARDL model is unable to quantify. This opens up room for nonlinearity. This is incorporated into the NARDL model with structural change and outliers (equation 7), thus presenting favourable results; that is, variables are cointegrated (except for the t-bounds-test, with 1\% significance), and there are no diagnostic or specification problems. Moreover, $\mathrm{R}^{2}$ and Adjusted R-squared achieve their maximum value and all information criteria reach their minimum. For all these reasons, the rest of the analysis focuses on this latest model.

Equation 7 is showed in Table 2, which has been divided into five parts. Parts 1 and 2 are brief. The adjustment is shown in part 1, where the coefficient is negative and less than 1, as required by error correction model theory (Engle \& Granger, 1987). Part 2 contains the self-regressive part of the model. It highlights the fact that the first four lags are significant, not so lags five to nine, but lags ten and eleven are significant again, thus suggesting a pattern of seasonality in rice imports (note the change in sign and magnitude of the coefficients).

Table 2. NARDL estimation with structural change and outliers (equation 7).

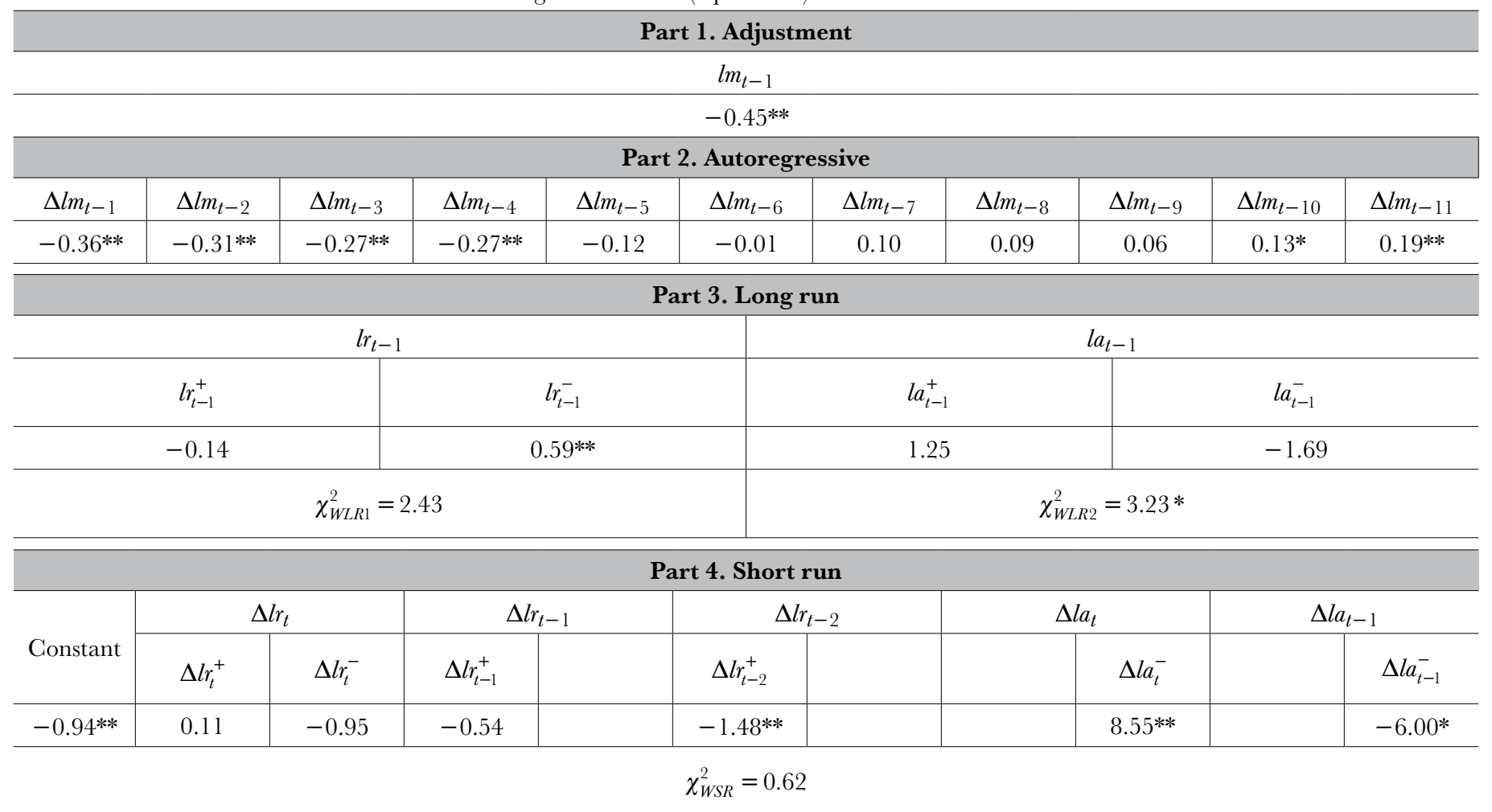

\begin{tabular}{c|c|c|}
\hline \multicolumn{3}{|c|}{ Part 5. Dummy variables } \\
\hline$d 2003$ & $d 2008 \_m 9$ & $d 2016 \_m 5$ \\
\hline $0.22 * *$ & $-1.09 * *$ & $-0.97 * *$ \\
\hline
\end{tabular}

Note: $l$ denotes natural logarithm of the variable, $\Delta$ means difference, $m$ is rice imports, $r$ is the exchange rate, and $a$ is the Global Indicator of Economic Activity. The superscripts ${ }^{+}$and $^{-}$denote positive and negative components of the corresponding variables. The Wald test for long-run symmetry is $\chi_{W L R}^{2}$, and $\chi_{W S R}^{2}$ for the additive short-run symmetry. The superscripts * and ** indicate significance at $10 \%$ and $5 \%$ level, respectively. 
Parts 3 and 4 focus on the long- and short-run effects, respectively. With respect to the long run, only the coefficient of $l r_{t-1}^{-}$is significant, with the expected positive sign; that is, an exchange rate appreciation increases rice imports. It would be appropriate to evaluate the absence or presence of symmetry with the null hypothesis $l r_{t-1}^{-}=l r_{t-1}^{+}$, the Wald test $\left(\chi_{W L R 1}^{2}\right)$ suggesting symmetry. However, as mentioned above, only $l r_{t-1}^{-}$is significant, not $l r_{t-1}^{+}$. In this way, the presence of long-run asymmetry is indirectly confirmed: only appreciations and not depreciations have effects on imports. As for the GIEA, because no coefficient is significant, its long-run effect on imports is ruled out. Notice that $\chi_{W L R 2}^{2}$ suggests asymmetry, with significance at $10 \%$. But $l a_{t-1}^{-}$and $l a_{t-1}^{+}$are not significant.

With respect to the short term, in addition to the constant, only the coefficients of $\Delta l r_{t-2}^{+}, \Delta l a_{t}^{-}$, and $\Delta l a_{t-1}^{-}$are significant. The negative sign of the coefficient of $\Delta l r_{t-2}^{+}$ indicates that a depreciation reduces rice imports. For its part, the positive sign of the coefficient of $\Delta l a_{t}^{-}$indicates that a decrease in economic activity increases imports, suggesting that rice is a grain which shows immediate increases in consumption and storage in difficult times: storage since lag $\left(\Delta l a_{t-1}^{-}\right)$shows a negative sign, thus indicating a reduction in imports. All these variables are significant, but there are not counterparts $\left(\Delta l r_{t-2}^{-}, \Delta l a_{t}^{+}\right.$, and $\left.\Delta l a_{t-1}^{+}\right)$, which indirectly expresses the existence of shortterm asymmetry (adjustment and cumulative short-run asymmetry). However, there is no short-run asymmetry effect; the Wald test $\left(\chi_{W S R 1}^{2}\right)$ suggests symmetry, but $\Delta l r_{t}^{-}$and $\Delta l r_{t}^{+}$are not statistically significant ${ }^{[5]}$.

Part 5 assesses the presence of structural change (d2003) and outliers (d2008_m9 and $\left.d 2016 \_m 5\right)$. The dummy variable is statistically significant, supporting a conclusion that the elimination of tariffs in 2003 increased rice imports. Variables $d 2008 \_m 9$ and $d 2016 \_m 5$ represent the 2008 crisis as well as Hurricane Patricia in late 2015. Both are statistically significant, thus indicating that these extraordinary events had an impact on imports, not permanently but only in the indicated month.

Finally, the results obtained have two important characteristics. First, they are consistent with the hypothesis raised. And second, they are different from previous studies of Mexican demand for imports. (Cardero \& Galindo, 1999; Cermeño \& Rivera Ponce, 2016; Loria Díaz, 2001; Moreno-Brid, 2002; Pacheco-López, 2005; Romero, 2010; Valencia, 2008). Not only do the results analyse a particular crop, but they also indicate for the first time an asymmetric response of Mexican demand for rice imports.

\section{CONGLUSIONS}

This study, through a NARDL model, provides evidence of asymmetry, structural change, and the presence of outliers in Mexican rice imports during NAFTA (1994-2018). With regard to asymmetry, only exchange rate appreciations affected rice imports in the long run; in the short run, these were affected by depreciation, as well as a decline in the

\footnotetext{
${ }^{5}$ Adjustment asymmetry is defined as $\Delta l a_{t}^{-}$and $\Delta l a_{t}^{+}$taking different lag orders, and cumulative asymmetry when $\sum \varphi_{j}^{-} \neq \sum \varphi_{j}^{+}$. And a short-run asymmetry effect is present if at the same lag order $j$, estimates of $\varphi_{j}^{-}$ are different than those of $\varphi_{j}^{+}$(Bahmani-Oskooee, Xi, and Bahmani, 2019).
} 
Global Indicator of Economic Activity. Regarding structural change, the elimination of import tariffs in Mexico in 2003 led to an increase in rice imports. With respect to outliers, there were two outstanding changes in rice imports. First, Patricia Hurricane affected the main rice-producing areas in Mexico (its occident part of Mexico), thus generating an extraordinary increase in rice imports in May 2016. And second, the financial crisis in 2008 created an exceptional exchange rate instability and, therefore, instability in the purchase of rice imports in September 2008.

Without a doubt the results found here are important for producers (domestic as well as foreign) and the Mexican government. As for producers, increased imports during NAFTA suggest a growing market - a market in a period of liberalization in which the most competitive producer would undoubtedly succeed. Hence the importance of these results for the Mexican government because the production of an essential grain must undoubtedly be dealt with strategically, for example, by strengthening infrastructure, minimizing intermediaries, and increasing $\mathrm{R} \& \mathrm{D}$, all to create a more competitive market.

\section{REFERENGES}

Bahmani-Oskooee, M., \& Nayeri, M. M. (2020). Policy uncertainty and the demand for money in the United Kingdom: Are the effects asymmetric? Economic Analysis and Policy, 66, 76-84. doi: 10.1016/j. eap.2020.02.005

Bahmani-Oskooee, M., Xi, D., \& Bahmani, S. (2019). More evidence on the asymmetric effects of exchange rate changes on the demand for money: evidence from Asian. Applied Economics Letters, 26(6), 485-495. Doi: 10.1080/13504851.2018.1486979

BANXICO. (2019). Sistema de Información Económica. Disponible en: http://www.banxico.org.mx/SieInternet/co nsultarDirectorioInternetAction.do?sector $=6 \&$ accion $=$ consultarCuadro\&idCuadro $=$ CR60\&locale $=\mathrm{es}$

Cardero, M. E., Galindo, L. M. (1999). La demanda de importaciones en México: un enfoque de elasticidades. Comercio Exterior, 49(5), 481-487.

Cermeño, R. S., Rivera Ponce, H. (2016). La demanda de importaciones y exportaciones de México en la era del TLCAN. Trimestre Económico, 83(1), 127-147. doi: 10.20430/ete.v83i329.198

Chi, J. (2018). Imperfect reversibility of fuel demand for road transport: Asymmetric and hysteretic effects of income and price changes in Korea. Transport Policy, 71, 116-125. Doi: 10.1016/j.tranpol.2018.08.006

Engle, R. F., Granger, C. W. J. (1987). Co-Integration and Error Correction: Representation, Estimation, and Testing. Econometrica, 55(2), 251-276. Doi: 10.2307/1913236

FAO. (2004). El Arroz y la Nutrición Humana. En Año Internacional del Arroz. Disponible en: http://www.fao. org/rice2004/es/f-sheet/hoja3.pdf

FAO. (2019). FAOSTAT. Organización de las Naciones Unidadas para la Alimentación y la Agricultura. Disponible en: http://www.fao.org/faostat/es/\#data

Goldstein, M., Khan, M. S. (1985). Income and price effects in foreign trade. Handbook of International Economics, 2, 1041-1105. Doi: 10.1016/S1573-4404(85)02011-1

INEGI. (2013). Encuesta Nacional de Gastos de los Hogares. INEGI. Disponible en: http://www3.inegi.org.mx/ rnm/index.php/catalog/132

INEGI. (2019a). Banco de Información Económica. Disponible en: https://www.inegi.org.mx/sistemas/bie/

INEGI. (2019b). Indicador Global de la Actividad Económica. Disponible en: https://www.inegi.org.mx/programas/ igae/2013/

Irandoust, M. (2019). On the relation between exchange rates and tourism demand: A nonlinear and asymmetric analysis. The Journal of Economic Asymmetries, 20(4), 1-10. Doi: 10.1016/j.jeca.2019.e00123

Ireta-Paredes, A. D. R., Altamirano-Cárdenas, J. R., Ayala-Garay, A. V., Covarrubias-Gutiérrez, I. (2015). Análisis macroeconómico y microeconómico de la competitividad del arroz en México. Agricultura Sociedad y Desarrollo, 12(4), 499. doi: 10.22231/asyd.v12i4.242.

Leamer, E. E., \& Stern, R. M. (1970). Quantitative International Economics. Routledge.

Liddle, B., \& Sadorsky, P. (2020). How much do asymmetric changes in income and energy prices affect energy demand ? The Journal of Economic Asymmetries, 21. Doi: 10.1016/j.jeca.2019.e00141 
Loria Díaz, E. (2001). La restricción externa y dinámica al crecimiento de México, a través de las propensiones del comercio, 1970-1999. Estudios Económicos, 16(2), 227-251.

Moreno-Brid, J. C. (2002). Liberalización Comercial y la Demanda de Importaciones en México. Investigación económica, 62,(240), 13-50.

Pacheco-López, P. (2005). The effect of trade liberalization on exports, imports, the balance of trade, and growth: The case of Mexico. Journal of Post Keynesian Economics, 27(4), 595-617.

Pesaran, M. H., Shin, Y. (1999). An Autoregressive Distributed-Lag Modelling Approach to Cointegration Analysis. En S. Strøm (Ed.), Econometrics and Economic Theory in the 20th Century: The Ragnar Frisch Centennial Symposium (pp. 371-413). Cambridge University Press. doi: 10.1017/CCOL521633230.011

Pesaran, M. H., Shin, Y., Smith, R. J. (2001). Bounds testing approaches to the analysis of level relationships. Journal of Applied Econometrics, 16(3), 289-326. doi: 10.1002/jae.616

Raheem, I. D. (2018). Dollarization: asymmetry and breaks. International Review of Applied Economics, 32(5), 697-710. doi: 10.1080/02692171.2017.1375465

Romero, J. (2010). Evolución de la demanda de importaciones de México: 1940-2009. En Documentos de trabajo (Número III). El Colegio de Mexico, Centro de Estudios Económicos.

SADER. (2020). Sistema de Información Agroalimentaria de Consulta. Mexico. Gobierno de México. Disponible en: https://www.gob.mx/siap/documentos/siacon-ng-161430

Shin, Y., Yu, B., Greenwood-Nimmo, M. (2011). Modelling Asymmetric Cointegration and Dynamic Multipliers in a Nonlinear ARDL Framework. SSRN, 1-61. doi: 10.2139/ssrn.1807745

Thirlwall, A. P. (2002). The Nature of Economic Growth. An Alternative Framework for Understanding the Performance of Nations. Edward Elgar Publishing. doi: 10.4337/9781843767466

Valencia, R. (2008). El modelo de crecimiento con restricción de balanza de pagos con incorporación de las remesas. El caso de México. Comercio Exterior, 58(1), 17-26.

Zahniser, S., Link, J. (2002). Effects of North American Free Trade Agreement on agriculture and the rural economy. Economic Research Service, USDA. 